\title{
O PAPEL DAS SÚMULAS NO DIREITO BRASILEIRO CONTEMPORÂNEO
}

\section{THE ROLE OF THE SUMULES IN CONTEMPORARY BRAZILIAN LAW}

\section{William Soares Pugliese ${ }^{1}$}

RESUMO: O presente artigo tem como objetivo avaliar o papel e o efeito das súmulas no direito brasileiro, uma vez que este instituto é de vital importância para a compreensão do Poder Judiciário. Para tanto, em um primeiro momento, tem-se uma análise da origem das súmulas no instituto dos assentos, do direito português. O trabalho procura focar, neste tópico, a forma como os assentos foram concebidos, sua função e, por fim, as razões pelas quais foram declarados inconstitucionais. Se, por um lado, os assentos foram afastados do direito português pela inconstitucionalidade, o Brasil acolheu o instituto em sua Constituição, por meio da Emenda Constitucional n. ${ }^{\circ} 45$, com as súmulas vinculantes previstas no art. 103-A. Por este motivo, o segundo item avalia o tratamento constitucional e legal do instituto. $\mathrm{O}$ último item problematiza o espaço das súmulas no direito brasileiro, questionando seu papel vinculante como produto da interpretação do Poder Judiciário, já que sua estrutura é mais semelhante à das leis que dos precedentes.

Palavras-chave: Súmulas; Precedente; Interpretação.

ABSTRACT: This article aims to evaluate the role and effect of the "súmulas" in Brazilian law, since this institute is of vital importance for the understanding of the Judiciary. To this end, at first, there is an analysis of the origin of the "súmulas" in the "assentos" institute, of Portuguese law. This paper focuses on how the "assentos" were designed, their function and, finally, the reasons why they were declared unconstitutional. If, on the one hand, the "assentos" were removed from Portuguese law by unconstitutionality, Brazil welcomed the institute in its

\footnotetext{
${ }^{1}$ Pós-Doutorando pela UFRGS. Professor do Programa de Pós-Graduação em Direito do Centro Universitário Autônomo do Brasil (Unibrasil). Mestre e Doutor em Direito pelo PPGD-UFPR. Gastforscher no Max-Planck-Institut für ausländisches öffentliches Recht und Völkerrecht. Coordenador da Especialização de Direito Processual Civil da Academia Brasileira de Direito Constitucional (ABDConst). Membro da Comissão de Estudos Constitucionais da Ordem dos Advogados do Brasil, Seção Paraná (OAB/PR). Advogado. william@pxadvogados.com.br. ORCID: https://orcid.org/0000-0002-5932-9076
} 
Constitution, through Constitutional Amendment No. 45, with the "súmulas" provided for in art. 103a. For this reason, the second item evaluates the constitutional and legal treatment of the institute. The last item problematizes the space of the "súmulas" in Brazilian law, questioning its binding role as a product of the interpretation of the Judiciary, since its structure is more similar to the laws than the precedents.

Key-words: Sumulas; Precedent; Interpretation.

Sumário: 1. Introdução; 2. A origem das súmulas nos assentos do Direito português; 3. A recepção das súmulas no Direito brasileiro; 4. Como uma súmula vincula; 5. Considerações Finais; 6. Referências.

\section{INTRODUÇÃO}

O direito brasileiro tem, nas súmulas, um elemento de peculiaridade histórica e estrutural. Afinal, a proposta de se organizar o entendimento dos tribunais em enunciados teve como intenção inicial servir como uma metodologia de trabalho. Com o passar do tempo, o que era uma simples técnica de compilação de entendimentos passou a ter outros efeitos, culminando com a previsão constitucional do instituto das súmulas vinculantes. Assim, se o constituinte derivado alçou as súmulas ao patamar constitucional, conferindo-lhes efeitos obrigatórios para os juízes e para a administração pública, faz-se necessário refletir sobre o papel e o efeito das súmuas no direito contemporâneo.

O presente artigo tem como objetivo, justamente, avaliar o papel e o efeito das súmulas no direito brasileiro. Esta reflexão é relevante e necessária. Trata-se de uma reflexão relevante porque o instituto é amplamente utilizado pelos tribunais superiores, razão pela qual sua presença não pode, nem deve, ser negada ou refutada pela doutrina. Ademais, a reflexão é necessária porque, cada vez mais, a lei brasileira confere efeitos próprios para as súmulas, sejam elas vinculantes ou não. Vale registrar, por exemplo, que as súmulas dos tribunais superiores são de observância obrigatória pelo Poder Judiciário, nos termos do art. 927, do Código de Processo Civil. 
Para desenvolver esta proposta, o artigo possui três itens. Em um primeiro momento, tem-se uma análise da origem das súmulas no instituto dos assentos, do direito português. $\mathrm{O}$ trabalho procura focar, neste tópico, a forma como os assentos foram concebidos, sua função e, por fim, as razões pelas quais foram declarados inconstitucionais.

Se, por um lado, os assentos foram afastados do direito português pela inconstitucionalidade, o Brasil acolheu o instituto em sua Constituição, por meio da Emenda Constitucional n.o 45, com as súmulas vinculantes previstas no art. 103-A. Por este motivo, o segundo item avalia o tratamento constitucional e legal do instituto. O último item problematiza o espaço das súmulas no direito brasileiro, questionando seu papel vinculante como produto da interpretação do Poder Judiciário, já que sua estrutura é mais semelhante à das leis que dos precedentes.

\section{A ORIGEM DAS SÚMULAS NOS ASSENTOS DO DIREITO PORTUGUÊS}

A técnica de "sumular" resultados de julgamentos não é uma ideia original brasileira. Na verdade, o método de sintetizar um entendimento dos tribunais e atribuir-lhe autoridade, que inspirou as súmulas brasileiras ${ }^{2}$, foi desenvolvido em Portugal e remonta a antecedentes históricos da Segunda Ordenação, quando eram produzidos pela Casa da Suplicação (PORTUGAL, 1994, p. 118). Contemporaneamente, os assentos eram instituto autorizado pelo artigo $2 .^{\circ}$, do Código Civil português, que dispunha o seguinte: “[n]os casos declarados na lei, podem os tribunais fixar, por meio de assentos, doutrina com força obrigatória geral". 3 Tanto os assentos eram utilizados que o Superior Tribunal de Justiça

\footnotetext{
${ }^{2}$ Quando o trabalho se referir à súmulas, sem qualificá-las como vinculantes, trata-se de um comentário que vale para qualquer espécie de súmula, seja ela vinculante ou não.

${ }^{3}$ Disponível em: 〈http://www.stj.pt/ficheiros/fpstjptlp/portugal_codigocivil.pdf>. Acesso em: 04 jun. 2016.
} 
português, a Corte Constitucional daquele Estado, editava-os com frequência até o ano de 1993, data em que foram declarados inconstitucionais pelo próprio tribunal que tinha competência para produzi-las. Por conta da experiência e das reflexões sobre o tema dos assentos, a presente análise parte de algumas considerações da doutrina e da jurisprudência portuguesa.

Cabe, porém, uma advertência preliminar: deve-se deixar claro que os assentos portugueses são, de fato, muito semelhantes às súmulas no que toca ao conteúdo abordado e à técnica utilizada para redigi-los. Veja-se, por exemplo, alguns dos últimos assentos editados pelo Supremo Tribunal de Justiça português. Ao tratar dos efeitos do recurso de revista em casos de falência, por exemplo, a Corte portuguesa assentou, em 1992, que o "recurso de revista de acórdão que conheça do estado de falência tem efeito meramente devolutivo" (PORTUGAL, 1992, s/p). Em 1989, o tribunal sustentou que "[s]ão públicos os caminhos que, desde tempos imemoriais, estão no uso directo e imediato do público" (PORTUGAL, 1989, s/p). Além disso, existem assentos sobre direito privado, como um de 1987, pelo qual, "[n]o domínio de vigência do Decreto-Lei n. ${ }^{\circ} 46.673$, de 29 de novembro de 1965, a falta de licença de loteamento não determina a nulidade dos contratos de compra e venda de terrenos, com ou sem construção, compreendida no loteamento" (PORTUGAL, 1987, s/p).

Por meio dos exemplos acima indicados, constata-se uma semelhança real entre os institutos, pois os textos são sintéticos, objetivos, com a intenção de atingir um contexto geral e abstrato. Pela força emprestada ao Código Civil português, os assentos também teriam força obrigatória geral. Justamente por isso, Castanheira Neves, ao explicar os motivos que o levaram a autorizar a reimpressão de obra sobre o tema, datada originalmente de 1983, destaca a importância dos assentos para o pensamento jurídico brasileiro, "preocupado que continua a estar em discutir o sentido e a admissão das 'súmulas vinculantes' não obstante a sua afinal instituição, a arrostar com todos os ventos de oposição crítica" $(2014$, p.1). A preocupação é 
justificada pois assentos e súmulas são figuras muito semelhantes não apenas pelos efeitos previstos, mas pela forma de abordagem e pela técnica de redação empregada pelos tribunais competentes para editá-las. ${ }^{4}$

Retome-se o foco: os assentos portugueses eram atos do Supremo Tribunal de Justiça que, em composição plena, poderia emitir enunciados para resolver um conflito de jurisrudência e "que se vêm a traduzir na conversão da doutrina ou posição jurídica, por que o tribunal se decida na solução desse conflito, numa prescrição normativa 'com força obrigatória geral'"(CASTANHEIRA NEVES, 2014, p.2). Para Castanheira Neves, o assento era uma figura original por conferir a um órgão judicial a competência para prescrever critérios jurídicos universalmente vinculantes pelo enunciado de normas, "no sentido estrito de normas gerais, ou de preceitos gerais e abstratos" (p.3), que se abstraem e se destacam do caso que the deu origem, com o propósito de "estatuírem para o futuro, de se imporem em ordem a uma aplicação futura" (p.4). Para Castanheira Neves, portanto, os assentos eram meios pelos quais os tribunais poderiam editar prescrições normativas independentemente do caso que havia sido julgado (p.5).

$\mathrm{O}$ autor não tarda a afirmar que os assentos são figuras distintas dos precedentes. Para ele, acertadamente, os precedentes são firmados pela argumentação, pela "orientação jurídica" adotada em um caso, pelo que fazem parte da jurisprudência e orientam as decisões de casos futuros. ${ }^{5}$ Os assentos, por sua vez, são dotados de autoridade distinta, porque impõem "mediante uma norma expressamente formulada para o futuro a solução de um conflito de jurisprudência" (CASTANHEIRA NEVES, 2014, p.11). Para não deixar dúvidas, Castanheira

\footnotetext{
${ }^{4}$ Vale a observação de que, mesmo após ter declarado inconstitucional o instituto dos assentos, o Superior Tribunal de Justiça português continua empregando a técnica de redação que sintetiza os argumentos jurídicos de um caso, o que será objeto de crítica ao se tratar das súmulas e das ementas, no Brasil.

5 "O precedente é uma concreta decisão jurisprudencial, vinculada como tal ao caso historicamente concreto que decidir." (CASTANHEIRA NEVES, 2014, p.12). Na mesma linha, sobre os precedentes, v. MARINONI, 2016; MITIDIERO, 2016; PUGLIESE, 2017. Da própria common Law, destacam-se as obras de EISENBERG, 1988; CROSS; HARRIS, 1991.
} 
Neves repete: "assento é norma (constitui-se ex-novo visando o futuro) e não jurisprudência (consagração de soluções que vêm do passado e persistem)" (p.11). A partir dessa conclusão a respeito do conceito legal dos assentos, o autor propõe uma análise em três planos: teleológico-jurídico, dogmático-jurídico e institucional.

No aspecto teleológico, tem-se que a razão de ser dos assentos é conferir maior estabilidade, segurança e igualdade nas decisões. Com as reformas judiciárias empreendidas no século XIX, em Portugal, esperava-se que a existência de uma corte de vértice $^{6}$ fosse suficiente para a uniformização da jurisprudência. A concepção do sistema recursal portugês foi sintetizada pelo Acórdão que julgou a constitucionalidade dos assentos: "o Supremo diria, a propósito de cada caso particular, em que sentido devia a lei ser interpretada e aplicada; os tribunais inferiores teriam de acatar as determinações do Supremo em relação ao caso em litígio" (PORTUGAL, 1994, p.120). A ideia original, portanto, era a de instaurar um sistema precedentalista, pautado pelo stare decisis e pelo respeito das decisões dos tribunais superiores pelos tribunais e magistrados submetidos àquela corte.

Não foi o que ocorreu: "em lugar da desejável jurisprudência uniforme, existia uma jurisprudência variável, flutuante e incerta, alimentada pela tendência individualista da liberdade de opinião dos magistrados judiciais, pouco atreitos a uma apertada disciplina de colegialidade interpretativa das leis" (PORTUGAL, 1994, p.120). O ideal buscado ainda era a uniformização e a certeza, mas o desrespeito das decisões levou a adoção de medidas mais incisivas. Exemplo delas foi o Decreto . $^{\circ} 4.620$, de 16 de junho de 1918, que exigia que os juízes seguissem a orientação do Superior Tribunal de Justiça e autorizava somente o pleno daquela corte a revisar seus entendimentos (PORTUGAL, 1994, p.121). Era, na época, uma

\footnotetext{
${ }^{6}$ Sobre o tema, MITIDIERO, 2014.
} 
saída mais próxima aos precedentes do que aos assentos e que recebe elogios até hoje, mas esteve em vigor por menos de um ano. ${ }^{7}$

Com a Ditadura Militar instaurada, em 1926, implementou-se a tarefa de reformar o direito processual civil e, com ela, ampliar a segurança sem estagnar o Direito. Aqui, com recurso à tradição portuguesa, resgataram-se os assentos no Código de Processo Civil de 1939, que teriam força obrigatória até que fossem revistos pelo Supremo Tribunal de Justiça. Essa possibilidade de revisão restrita garantia, em tese, a segurança e a flexibilidade do Direito. ${ }^{8}$ Em outras palavras, reforçava-se a certeza com mais prescrições com força de lei (PORTUGAL, 1994, p.124). O Direito português manteve essa estrutura enquanto vigorou a lei processual de 1939. Com o Código de Processo Civil português de 1961, porém, a preocupação com a estagnação foi abandonada, uma vez que se excluiu da lei a faculdade do Supremo Tribunal de Justiça alterar o que já havia assentado.

O problema foi rapidamente resolvido, tendo a matéria dos assentos sido revogada do Código de Processo Civil e reformulada no Código Civil, de 1966, que voltou a permitir sua revisão pelo pleno do Supremo Tribunal de Justiça e afirmava seu caráter obrigatório para os demais magistrados. Chega-se, enfim, ao dispositivo cuja consitucionalidade foi questionada perante o Superior Tribunal de Justiça. Os comentários feitos ao dispostivo seguiam a linha teleológica originária, defendendoo pela eficácia que teria ao vincular o posicionamento dos tribunais ao entendimento da corte constitucional. Segurança, certeza e igualdade, sem engessamento, era a fórmula que acompanhava a justificação dos assentos. Castanheira Neves conclui, sobre a teleologia dos assentos, que dois valores foram essenciais: "o valor da segurança e ou certeza do direito e o valor da igualdade jurídica" (2014, p.269).

\footnotetext{
7 “Sábo regime este a que só faltou a devida compreensão por parte do nosso pensamento jurídico para que pudesse ter obtido o êxito que merecia, mas que efectivamente não teve: revogado no ano seguinte ao de sua instituição." (CASTANHEIRA NEVES, 2014, p. 193).

${ }^{8}$ Talvez a melhor expressão para designar essa flexibilidade, em oposição à estagnação, seria a "mitezza" italiana. Neste sentido, ver: ZAGREBELSKY, 1992.
} 
Ocorre que esses valores foram concebidos em um momento no qual o Direito buscava desenvolver os conceitos sob uma perspectiva formal. ${ }^{9}$ Assim, a busca pela segurança e pela igualdade foi pautada por uma predeterminação formal e pela noção de igualdade formal. Outro não poderia ser o resultado: "uma estrutura também formal e geral-abstracta do direito, uma vez que só mediante esta estrutura a pré-determinação encontraria o modo de obectivização adequado e a igualdade seria susceptível de se realizar na prática" (CASTANHEIRA NEVES, 2014, p.269). O que Castanheira Neves afirma, portanto, é que os assentos têm a estrutura de leis ou enunciados normativos ${ }^{10}$ para resolver o problema de insegurança e desigualdade gerado pelas leis. ${ }^{11}$ Evidentemente, seu pensamento prossegue com uma crítica incisiva:

Os assentos significam, pois, um legalismo de segundo grau ou elevado a segunda potência, um legalismo resistente e à outrance que, não se conformando com a superação que dele impõem as exigências normativas da histórica realização jurídica e não aceitando a verdadeira função prático-normativa da jurisprudência, força a sua própria recuperação a esse mesmo nível da realização histórico-jurisprudencial do direito em que se vê superado (CASTANHEIRA NEVES, 2014, p.270).

Mesmo sem concordar com a opção do Estado português, Castanheira Neves admitia, em 1983, a necessidade de se compreender os assentos e identificar seu papel no ordenamento jurídico. Isto o levou a uma análise dogmático-jurídica, que

\footnotetext{
${ }^{9}$ Sobre a mudança de perspectivas jurídicas, v. MACEDO JR., 2013 e KOZICKI, 2012.

${ }^{10}$ Existem opiniões contrárias. Para Jorge Miranda, por exemplo, a estrutura semelhante a da lei não pode ser vista como um problema em si: "Não se tratava de normas legislativas nem de interpretação autêntica em acesção própria: faltava-lhe o irrecusável elemento político que nestas sempre se exibe. Tratava-se, sim, de normas jurisprudenciais, o que explicava a sua necessária acessoriedade perante a lei a que correspondiam, bem como as limitações da sua emanação. Nem se outorgava ao tribunal pleno, por fixar doutrina, um poder de direção dos tribunais contrário à sua independência; ele não procedia senão à formulação de uma proposição - não de todas as preposições do juízo jurisprudencial." (MIRANDA, 2015, p.376).

11 "O resultado foi a imposição dos esquemas do legalismo ao nível da própria jurisprudência, prescrevendo que ela fizesse também seus esses esquemas, de um legalismo geral-abstracto, num momento fundamental da sua actividade." (CASTANHEIRA NEVES, 2014, p.270).
} 
também foi realizada pelo Supremo Tribunal de Justiça quando do julgamento da constitucionalidade do artigo 2. ${ }^{\circ}$, do Código Civil português. Neste âmbito, havia duas correntes bem delimitadas: por um lado, autores sustentavam a natureza jurisdicional dos assentos ${ }^{12}$, enquanto outros afirmavam sua natureza legislativa. ${ }^{13} \mathrm{~A}$ Corte entendeu que os assentos tinham caráter de fonte do direito ${ }^{14}$, mais especificamente de norma jurídica, tanto é que poderiam se sujeitar a juízos de inconstitucionalidade pela via direta e abstrata. ${ }^{15}$ Esta posição foi confirmada pela remissão a diversos julgados anteriores da corte. Concluiu o Supremo Tribunal de Justiça português que "os assentos se apresentam com carácter prescritivo, constituindo verdadeiras normas jurídicas com o valor de 'quaisquer outras normas do sistema', revestidas de carácter imperativo e força obrigatória geral" (PORTUGAL, 1994, p.136). Se os assentos eram normas, obrigavam os tribunais, as autoridades e a comunidade jurídica em geral.

A partir dessa compreensão, a corte portuguesa reconheceu que sua atividade deveria ser jurisdicional, e não legislativa, e pela violação dos preceitos da Constituição de Portugal declarou inconstitucional o artigo $2 .^{\circ}$, do Código Civil. A função dos tribunais não seria a de editar novas normas, mas a de orientar a interpretação do ordenamento vigente - na esteira da proposta institucional de

\footnotetext{
12 Além de Jorge Miranda, destacam-se: ASCENSÃO, 1987 e VARELA, 1992.

${ }^{13}$ Além de Castanheira Neves, destaca-se CANOTILHO, 1992.

${ }^{14} \mathrm{Na}$ senda de Castanheira Neves: "Tomando posição no âmbito da controvérsia, este Autor define o sentido dogmático dos assentos em termos de uma prescrição jurídica (imperativo ou critério normativo-jurídico obrigatório) que se constitui no modo de uma norma geral e abstracta, proposta à pré-determinação normativa, de uma aplicação futura, susceptível de garantir a segurança e a igualdade jurídicas, e que não só se impõe com a força ou eficácia de uma vinculação normativa universal como se reconhece legalmente com o carácter de fonte de direito, com o que assumem a natureza de uma disposição legislativa." (PORTUGAL, 1994).

15 "A fixação de doutrina com força obrigatória geral operada através dos assentos, traduz a existência de uma norma jurídica com eficácia erga omnes, em termos de, quanto a ela, ser possível o accionamento do processo de fiscalização abstracta sucessiva de constitucionalidade." (PORTUGAL, 1994)
} 
Castanheira Neves. Deste modo, os assentos e a competência para assentar foram excluídos do ordenamento jurídico português. ${ }^{16}$

É de se registrar, porém, que o Supremo Tribunal de Justiça de Portugal ainda se utiliza de proposições objetivas ${ }^{17}$, as quais denomina de Acórdãos, como meio para uniformizar sua jurisprudência, mas não mais sustenta que esses enunciados possuem eficácia geral ou força obrigatória.

O que Portugal nunca fez foi conferir aos assentos previsão constitucional. O Brasil, mesmo consciente da conclusão portuguesa sobre o tema, insistiu nas súmulas como meio para assegurar a segurança, a certeza e a igualdade. Vistas, de início, como uma técnica para assegurar tais valores, as súmulas tomaram maior importância por meio de reformas no Código de Processo Civil de 1973, realizadas na década de 90, pela qual a existência de súmulas passou a justificar a tomada de decisões monocráticas nos tribunais, a rejeição ou o provimento de recursos com maior celeridade, dentre outros efeitos. Não satisfeito, o poder constituinte derivado brasileiro alçou a súmula a um novo patamar com a Emenda Constitucional n. ${ }^{\circ}$ 45/2004. Nela, criou-se o instituto da súmula vinculante, no artigo 103-A, dotada de "efeito vinculante" em relação aos órgãos do Poder Judiciário e à administração pública.

O Brasil percorreu o mesmo caminho de Portugal: para obter maior segurança, certeza e igualdade nas decisões optou-se por um instituto marcado pela estrutura formal, semelhante ou idêntica a da própria lei. Teleologicamente, portanto, subscreve-se a crítica de Castanheira Neves, sendo a súmula uma técnica inadequada para o enfrentamento das questões jurídicas contemporâneas. Afinal, os problemas de interpretação das leis não se resolvem com mais leis, mas com

\footnotetext{
16 "O instituto dos assentos, tal como o conhecemos e está definido na lei, ficará irremediavelmente prejudicado por inconstitucionalidade.” (LAPA, 1994).

17 Por exemplo, “[o]s imóveis construídos por empresa de construção civil, destinados a comercialização, estão excluídos da garantia do privilégio imobiliário especial previsto no art. $377 .^{\circ}$, n. ${ }^{\circ}$ 1, al. b), do Código do Trabalho de 2003.” (PORTUGAL. 2016)
} 
argumentos coerentes e íntegros. É esta a linha que se passa a investigar no item abaixo.

\section{RECEPÇÃO DAS SÚMULAS NO DIREITO BRASILEIRO}

Como se mencionou ao final do item acima, as súmulas foram instauradas no Brasil com o objetivo mediato de fornecer maior segurança, certeza e igualdade nas decisões. Na época, porém, a estrutura formal, semelhante à própria lei, não foi considerada como um impeditivo relevante contra o instituto. Como relata Daniel Mitidiero (2016, p.83), as súmulas ingressam no ordenamento jurídico brasileiro por meio de emenda ao Regimento Interno do Supremo Tribunal Federal, em 1963. Originariamente, foram elas concebidas como enunciados gerais e abstratos que visavam a informar, rapidamente, os Ministros acerca do entendimento do próprio Supremo Tribunal Federal sobre uma determinada questão. É justamente por isso que o autor afirma, com respaldo em Leal (1981), que o papel originário do instituto, no Brasil, era o de um "método de trabalho". Serviam, portanto, para que o próprio Supremo Tribunal Federal conhecesse seus entendimentos.

De 1963 até hoje, porém, o instituto sofreu uma intensa transformação. As súmulas são muito mais do que um método de trabalho. Hoje, há menos dois dispositivos que as colocam em uma posição bastante diversa. Em primeiro lugar, o art. 103-A, da Constituição da República Federativa do Brasil, admite a edição das chamadas súmulas vinculantes, cuja aplicação é obrigatória pelos demasi órgãos do Poder Judiciário e da administração pública direta e indireta. Mais do que isso, o art. 927, IV, do Código de Processo Civil, prevê que as súmulas do STF e do STJ devem ser observadas pelos juízes e tribunais. Essas regras, vale lembrar, são muito semelhantes às do Código Civil português, as quais foram declaradas inconstitucionais. 
Apesar disso, não há, no Brasil, a possibilidade de se argumentar a inconstitucionalidade das súmulas vinculantes, salvo a hipótese de a norma constitucional ser inconstitucional. ${ }^{18}$ Como o Supremo Tribunal Federal vem se utilizando dessa técnica, sem questionar qualquer incompatibilidade com o texto constitucional, não parece suficiente encerrar os argumentos com a mesma conclusão do Supremo Tribunal de Justiça português. O mesmo vale para os efeitos conferidos às súmulas pelo Código de Processo Civil, uma vez que os tribunais superiores vem, reiteradamente, utilizando-se dessa técnica. Para prosseguir, é preciso enfrentar, no sentido dogmático-jurídico, a natureza e os efeitos da súmula vinculante. Veja-se, como ponto de partida, o tratamento constitucional da matéria. ${ }^{19}$

Pelo caput do dispositivo observa-se que a edição da súmula vínculante deve ocorrer após reiteradas decisões sobre matéria constitucional. Nesta senda, o objetivo da Constituição parece derivar da constatação de uma posição uniforme da jurisprudência do Supremo Tribunal Federal sobre matéria constitucional em controle difuso - fosse controle concentrado, a decisão por si só teria efeito vinculante. Identificada a matéria que já foi objeto de reiteradas decisões, o tribunal pode aprovar a súmula vinculante mediante decisão de dois terços de seus membros.

${ }^{18}$ Sobre o tema, ver: BACHOF, 2009.

${ }^{19}$ Art. 103-A. O Supremo Tribunal Federal poderá, de ofício ou por provocação, mediante decisão de dois terços dos seus membros, após reiteradas decisões sobre matéria constitucional, aprovar súmula que, a partir de sua publicação na imprensa oficial, terá efeito vinculante em relação aos demais órgãos do Poder Judiciário e à administração pública direta e indireta, nas esferas federal, estadual e municipal, bem como proceder à sua revisão ou cancelamento, na forma estabelecida em lei.

$\S 1 .^{\circ}$ A súmula terá por objetivo a validade, a interpretação e a eficácia de normas determinadas, acerca das quais haja controvérsia atual entre órgãos judiciários ou entre esses e a administração pública que acarrete grave insegurança jurídica e relevante multiplicação de processos sobre questão idêntica.

$\S 2{ }^{\circ}$ Sem prejuízo do que vier a ser estabelecido em lei, a aprovação, revisão ou cancelamento de súmula poderá ser provocada por aqueles que podem propor a ação direta de inconstitucionalidade. $\S 3 .^{\circ}$ Do ato administrativo ou decisão judicial que contrariar a súmula aplicável ou que indevidamente a aplicar, caberá reclamação ao Supremo Tribunal Federal que, julgando-a procedente, anulará o ato administrativo ou cassará a decisão judicial reclamada, e determinará que outra seja proferida com ou sem a aplicação da súmula, conforme o caso. 
A razão de ser da súmula vinculante não é diversa dos assentos: decorre da busca por certeza, pela segurança e pela igualdade. ${ }^{20} \mathrm{~A}$ interpretação dogmático-jurídica nacional também não foge daquela proposta por Castanheira Neves: "por aí se pode ter introduzido uma nova fonte, ou ao menos uma nova forma de expressão do Direito - já que se trata de um enunciado normativo de características análogas à norma legal" (MANCUSO, 2014, p.330). Acresça-se ao argumento de Mancuso que a Constituição confere efeito vinculante a essas súmulas, o que pode ser compreendido como obrigatoriedade, o que reforça sua semelhança com a lei. O $\S$ $2 .^{\circ}$ do artigo 103-A é outro argumento que reforça sua semelhança com as normas, pois admite que se realize seu controle mediante requerimento dos legitimados para propor ação direta de constitucionalidade.

$\mathrm{O} \S 1 .^{\circ}$ do artigo acima citado procurava condicionar a edição de súmulas vinculantes apenas sobre temas de validade, interpretação e eficácia de normas determinadas, sobre as quais houvesse controvérsia entre órgãos do Poder Judiciário ou da administração pública e que acarretassem grave insegurança e multiplicação de processos. O problema é que, como alertou Castanheira Neves, não há como tratar da interpretação, da validade ou da eficácia de uma regra pela edição de uma nova regra com estrutura formal. Afinal, esta nova regra também será objeto de interpretação e o resultado esperado, que seria maior segurança jurídica e redução do número de processos, pode se inverter. Não se deve olvidar que a edição de uma regra, seja na lei, seja por súmula vinculante, é prática que exige uma apurada técnica de redação, o que nem sempre se revela na prática. Como destaca Gustavo de Castro Faria (2012, p.114), muitas vezes "a elaboração dos enunciados de súmulas não possibilita a aferição de seu real sentido, revelando situações cuja precariedade de sua construção não permite ao intérprete identificar com precisão os casos que efetivamente comportam sua aplicação". Em outras palavras, o que o

\footnotetext{
${ }^{20} \mathrm{Na}$ doutrina brasileira, os valores acima são utilizados para justificar as súmulas vinculantes por MANCUSO, 2014, p.321-341.
} 
autor afirma é que a súmula também pode gerar problemas de interpretação, de pertinência, de prova ou de qualificação - configurando, assim, um hard case, nos termos em que definidos por Neil MacCormick (2006). Estes problemas são inerentes à técnica legislativa e as súmulas não os afastam.

Também vale destacar que a previsão constitucional de que as súmulas terão por objetivo a validade, a interpretação e a eficácia de normas determinadas é um requisito que dificilmente pode ser atendido pela própria estrutura do instituto. O que permite defender a validade, a eficácia ou a interpretação de uma norma é a argumentação. Ao se reduzir a discussão do tribunal a uma afirmação sucinta e com efeitos vinculantes, deixa-se de lado a norma original e estabelece-se uma segunda norma, de "segundo grau" ${ }^{21}$, que impõe a validade, a eficácia ou um significado da primeira. Teoricamente, esta atividade é bastante complexa e, na prática, não se revela como a realidade. Ao se examinar o texto das súmulas vinculantes, vê-se que a maioria inova o ordenamento jurídico, ainda que todas possam ser justificadas a partir de uma norma determinada.

Veja-se, por exemplo, o texto da Súmula Vinculante n. ${ }^{\circ}$ 53: "[a] competência da Justiça do Trabalho prevista no art. 114, VIII, da Constituição Federal alcança a execução de ofício das contribuições previdenciárias relativas ao objeto da condenação constante das sentenças que proferir e acordos por ela homologados". Há interpretação do artigo 114, VIII, da Constituição, mas há um acréscimo ao conteúdo do texto constitucional. A súmula vinculante $n{ }^{\circ} 50$ também está no limite da interpretação e do acréscimo de conteúdo: “[n]orma legal que altera o prazo de recolhimento de obrigação tributária não se sujeita ao princípio da anterioridade.” A justificativa para tanto não é difícil de se encontrar: quem interpreta atribui um conteúdo ou uma intencionalidade ao texto (PUGLIESE, 2016). Se essa interpretação assume a estrutura de uma nova norma ela também estará sujeita à atuação de outros intérpretes.

${ }^{21}$ Conforme a definição de: CASTANHEIRA NEVES, 2014, p.270. 
A solução constitucional, portanto, padece do mesmo problema que ela buscava evitar: novas súmulas podem gerar mais incerteza e mais processos. Aliás, o artigo 103-A não só confirma essa consequência como indica o meio processual pelo qual é possível questionar, diretamente no Supremo, o descumprimento de súmulas - e, consequentemente, sua interpretação. Diz o $\S 3 .{ }^{\circ}$ que, do ato administrativo ou da decisão que contrariar a súmula vinculante, ou que indevidamente a aplicar, caberá reclamação. Pois bem, ao invés de reduzir os processos, a Constituição estabeleceu uma linha direta entre o desrespeito às súmulas e a autuação de um novo pedido no próprio Supremo Tribunal Federal. O objeto da reclamação é, em última instância, verificar se o texto da súmula foi corretamente aplicado. Trata-se, no fundo, da mesma lógica formal que define uma regra jurídica: "sempre que $\mathrm{FO}$, então $\mathrm{CN}$ ". A diferença é que, no caso da reclamação, é o próprio Supremo quem estabelece o Fato Operativo, a Consequência Jurídica e que interpreta a regra nos casos futuros.

O que é certo é que a súmula vinculante é um instituto de perplexidade, como consignou Castanheira Neves (2014, p.285) sobre os assentos. Trata-se de uma figura elaborada pelos tribunais, mediante autorização constitucional, com caráter prescritivo, revestidas de caráter imperativo para o Poder Judiciário e órgãos da administração pública (PORTUGUAL, 1994, p.136). Esse caráter imperativo é previsto pela Constituição como o efeito vinculante da súmula e, pelo Código de Processo Civil, como de observância obrigatória pelos demais juízes e tribunais. Cabe, agora, avaliar e compreender, adequadamente, a natureza deste efeito vinculante das súmulas. É o que se passa a examinar, no próximo item.

\section{COMO UMA SÚMULA VINCULA}

Para a compreensão da ideia de vinculação, adota-se, neste artigo, a proposta de vinculação extraída da obra de Neil MacCormick. As razões completas para 
tanto demandam outro artigo, mas podem ser aqui sintetizadas na ideia de que este autor concebeu uma proposta de vinculação que leva em consideração o papel da lei, dos precedentes e da argumentação jurídica no direito contemporâneo. Deste modo, o autor confere valor às interpretações prévias que atribuíram sentido aos dispositivos legais. Deste modo, o efeito vinculante pode ser compreendido nos termos da citação de MacCormick (2008, p.191): "uma vez decidido após análise cuidadosa, um caso deve ser tratado como se tivesse sido resolvido de uma vez por todas, a não ser que se possa demonstrar ter surgido um elemento especial que exija reconsideração".

O requisito da análise cuidadosa foi previsto constitucionalmente, embora sua constatação possa ser questionada por uma análise individual de cada súmula e da quantidade de casos julgados para configurar as "reiteradas decisões". Pela regra, ao menos, a edição da súmula vinculante pressupõe ampla discussão, a análise de diversos argumentos jurídicos e o voto favorável de dois terços dos Ministros. Feito isso, é razoável afirmar que a decisão possa ser tratada como se tivesse sido resolvida de uma vez por todas. O problema, aqui, é que o pensamento de MacCormick não considera que a decisão de um tribunal será convertida em texto semelhante ao da lei. Note-se que o autor afirma que "um caso deve ser tratado como se tivesse sido resolvido de uma vez por todas" (MacCORMICK, 2008, p.191), e a súmula não contém um caso propriamente dito. Assim, sua eficácia vinculante possui traços característicos das leis, admitidas as vicissitudes dessa estrutura formal que, como já apontado, pode gerar problemas de interpretação, pertinência, prova e qualificação.

Há, porém, uma solução dogmática para este tema que não corrige as súmulas já existentes, mas que pode condicionar a produção das futuras. Essa saída 
parece ter sido concebida pelo legislador quando da redação do Código de Processo Civil. Este dispotivo possui dois parágrafos, aqui reproduzidos. ${ }^{22}$

Enquanto o $\$ 10^{\circ}$ indica aos tribunais que editem súmulas de sua jurisprudência dominante - o que não acrescenta elementos relevantes para a discussão - o $§ 2 .^{\circ}$ merece ser considerado com atenção. Exige o Código que, ao editar os enunciados da súmula, os tribunais atentem-se às circunstâncias fáticas dos precedentes que motivaram sua criação. Em que pese a estrutura formal da súmula não seja abandonada, há ao menos a preocupação do legislador com a delimitação do âmbito de aplicação fática da regra formulada pelos tribunais. Esta exigência não transforma as súmulas em precedentes, mas permite àqueles que examinam seu texto identificar de modo mais claro as circunstâncias que ensejaram sua redação. Ao exigir dos tribunais que tratem dos fatos do caso a técnica da jurisprudência sumulada se aproxima do reconhecimento de que a decisão só se justifica, e só tem alguma aplicação, ao se partir da premissa de que casos iguais devem ser decididos de modo igual. É motivo de elogio, portanto, a previsão do Código de Processo Civil, muito embora sua aplicação ainda deva ser constatada na prática do Supremo Tribunal Federal. ${ }^{23}$

Por fim, a vinculação dos efeitos também exige sua excepcionalidade. Resta saber quais são as circunstâncias especiais que autorizam a reconsideração ou o afastamento do entendimento previsto na súmula. A primeira dessas hipóteses está prevista expressamente na Constituição, no artigo 103-A, § 2. ": "a aprovação, revisão ou cancelamento de súmula poderá ser provocada por aqueles que podem propor a ação direta de inconstitucionalidade". Com isso, os legitimados para o controle de constitucionalidade pela via direta podem requerer a revisão ou o

$22 \S 1 .^{\circ} \mathrm{Na}$ forma estabelecida e segundo os pressupostos fixados no regimento interno, os tribunais editarão enunciados de súmula correspondentes a sua jurisprudência dominante.

$\S 2 .^{\circ}$ Ao editar enunciados de súmula, os tribunais devem ater-se às circunstâncias fáticas dos precedentes que motivaram sua criação.

${ }^{23}$ Até o dia 05 de novembro de 2019, o Supremo Tribunal Federal não editou nenhuma súmula vinculante sob a vigência do Código de Processo Civil de 2015. 
cancelamento das súmulas vinculantes desde que tenham argumentos relevantes para tanto. O problema desta regra é que a edição da súmula não depende de requerimento dos legitimados pelo artigo 103, da Constituição. Ao contrário, a súmula vinculante pode ser editada de ofício, pelo Supremo Tribunal Federal, quando do julgamento de recursos extraordinários ou no exercício de qualquer outra competência. Ao reduzir o número de legitimados que podem participar do processo de revisão ou anulação das súmulas o instituto se fortalece no quesito "vinculante", mas demonstra um déficit democrático e flerta com a violação do contraditório e da ampla defesa. É preciso, portanto, identificar os meios pelos quais um indivíduo sem legitimidade para requerer o controle de constitucionalidade pela via direta pode usar para afastar a incidência da súmula vinculante.

As duas saídas partem da interpretação e da argumentação jurídicas. Como a superação do entendimento da súmula não pode ser discutida fora do Supremo Tribunal Federal, os litigantes podem discutir a interpretação do enunciado ou, ainda, buscar a diferenciação entre os casos que deram origem ao entendimento da Corte Constitucional com o atual.

A primeira solução consiste no afastamento da aplicação dedutiva da súmula vinculante, na qual o advogado procurará apontar alguma deficiência na redação do enunciado que gere a necessidade de maior argumentação que justifique, ou afaste, a aplicação do entendimento vinculante. Trata-se, portanto, de um exercício de retórica, na ótica de MacCormick. Tome-se como exemplo a Súmula Vinculante n. ${ }^{\circ}$ 27: “[c]ompete à Justiça estadual julgar causas entre consumidor e concessionária de serviço público de telefonia, quando a ANATEL não seja litisconsorte passiva necessária, assistente, nem opoente". Embora o texto não deixe dúvida quanto à competência do juízo, seria possível questionar, em um caso específico, se o autor é consumidor, nos termos legais, ou se o litisconsórcio com a ANATEL é necessário. A súmula vinculante $\mathrm{n}^{\circ} 1$ permite um raciocínio semelhante. Seu enunciado determina que "[o]fende a garantia constitucional do ato 
jurídico perfeito a decisão que, sem ponderar as circunstâncias do caso concreto, desconsidera a validez e a eficácia de acordo constante de termo de adesão instituído pela Lei Complementar n. ${ }^{\circ} 110 / 2001$ ”. Sua superação poderia se dar pela demonstração de que, em determinado caso, as circunstâncias do caso concreto não foram adequadamente ponderadas, o que afastaria a vinculação da súmula. Enfim, procurou-se demonstrar, em raciocínios simples, que as súmuas vinculantes podem ser excepcionadas se nelas se constatarem hipóteses que dependem de interpretação, não mera dedução.

A segunda solução está voltada aos fatos. Pela argumentação, é possível afastar a súmula caso se demonstre que o caso em análise não é semelhante ao que deu origem às súmulas. Tome-se como exemplo a discussão que deu origem à Súmula Vinculante n. ${ }^{\circ}$ 31, cujo texto aprovado foi o seguinte: "[é] inconstitucional a incidência do Imposto sobre Serviços de Qualquer Natureza - ISS sobre operações de locação de bens móveis". No debate de aprovação do enunciado, proposto pelo Ministro Joaquim Barbosa (STF, 2010, s/p), o Supremo Tribunal Federal partiu de um enunciado mais extenso e que exigia que as operações de locação de bens móveis fossem "dissociadas da prestação de serviços" (STF, 2010, p.1). Os Ministros Dias Toffoli, Cármen Lúcia e Ricardo Lewandowski votaram sem ressalvas, a favor do enunciado original. Coube ao Ministro Cezar Pelluso levantar a questão de que a inconstitucionalidade da incidência do ISS era sobre a locação de bens móveis, independentemente de sua relação com a prestação de serviços. ${ }^{24}$

\footnotetext{
24 "Veja bem: estamos afirmando que é inconstitucional quando incide sobre locação de móveis, mas só quando é dissociada da operação de serviço. Quando for associada, cabe imposto? Não. Então, a referência a 'dissociada' é desnecessária, porque, quando associada, também não incide. Quando há contrato de locação de móveis e, ao mesmo tempo, prestação de serviço, a locação de móveis continua não suportando o imposto; o serviço, sim. Se não tiver nenhuma ligação com prestação de serviço, também continua não suportando; não há incidência. Noutras palavras, o 'dissociada' aí realmente é inútil e pode gerar dúvida. E, quando for associada, está sujeita ao imposto sobre prestação de serviço? A meu ver, com o devido respeito, não há prejuízo algum ao sentido das inúmeras decisões, se for cortada a expressão final 'dissociada da prestação de serviço. É inconstitucional a indicência sobre locação de imóveis, só.” (BRASIL, 2010).
} 
No debate que a manifestação do Ministo Cezar Pelluso gerou, o Ministro Joaquim Barbosa justificou que o motivo pelo qual inseriu o trecho final no enunciado da súmula tinha como finalidade resolver as situações em que "a prestação de serviço vem escamoteada em forma de locação. Por exemplo: locação de maquinário, e vem o seu operador. Nessa hipótese, muito comum" (STF, 2010, p.6). O Ministro Pelluso insistiu que, nos casos cogitados pelo Ministro Joaquim Barbosa, só haveria incidência de imposto sobre a prestação de serviço e manteve a sugestão de eliminar o último trecho do enunciado. O que é interessante foi a resposta do Ministro Joaquim Barbosa: "como eu disse, não vejo essas questões periféricas que podem surgir aí, podem ser resolvidas em reclamação e em outros procedimentos" (STF, 2010, p.7). Aqui, manifestou-se a Ministra Cármen Lúcia: "O que o Ministro Pelluso aponta é sério. Nós temos que dar uma redação que não gere dúvida, porque, poder resolver por reclamação, é, de início, já acentuarmos que poderá haver dúvida" (STF, 2010, p.7). A resposta do Ministro Joaquim Barbosa já considerava o prosseguimento da discussão em outros momentos na corte: "que haverá reclamação, não tenho a menor dúvida. Reclamação virou a panaceia" (STF, 2010, p.10). Com isso, foi reduzido o texto do enunciado definitivo.

Observa-se que, no debate de aprovação, os próprios Ministros do Supremo Tribunal Federal reconheceram que a súmula vinculante seria objeto de debate fático, seja via reclamação, seja por outras vias recursais. Isto demonstra a necessidade de se examinar os casos e os fatos que deram origem às súmulas vinculantes a fim de identificar as semelhanças e as diferenças com um caso atual. Como se constatou no debate acima relatado, existem casos que não são cobertos pela Súmula Vinculante $n .{ }^{\circ} 31$ por força das circunstâncias fáticas que os conformam, e essas diferenças podem resultar em uma decisão diferente. Assim, pelo plano fático e probatório, é possível demonstrar circunstâncias especiais que autorizam o afastamento do entendimento previsto na súmula. 


\section{CONSIDERAÇÕES FINAIS}

Vinculantes ou não, as súmulas são uma das formas dos tribunais superiores brasileiros editarem regras que se aproximam da função dos precedentes. Mais do que isso, o Direito brasileiro impõe que as súmulas sejam observadas e, portanto, devem ser aplicadas em casos semelhantes.

Como o instituto encontra, hoje, previsão constitucional, não parece razoável imaginar que esse instituto será afastado do ordenamento pátrio, ao contrário do que ocorreu em Portugal. Deve-se presumir, portanto, que as súmulas têm um papel relevante no Direito e que assim devem ser compreendidas. De forma objetiva, o papel das súmulas é estabelecer a posição dos tribunais a respeito de questões relacionadas à validade, à interpretação e à eficácia de normas determinadas, sobre as quais há controvérsia e que acarretem insegurança e multiplicação de processos. Em outras palavras, visam delimitar a interpretação de um dispositivo pelos demais julgadores.

O problema desta metodologia, como alertado acima, é o de que não há como tratar da interpretação, da validade ou da eficácia de uma regra pela edição de uma nova regra. Isto abre espaço para nova interpretação e o resultado esperado, que seria maior segurança jurídica e redução do número de processos, pode se inverter. Não se deve olvidar que a edição de uma regra, seja na lei, seja por súmula, é prática que exige uma apurada técnica de redação, o que nem sempre se revela na prática. A forma de se afastar este problema está na atenta aplicação dos parágrafos do art. 926, do Código de Processo Civil, de modo que a edição das súmulas se atenha às cincunstâncias fáticas que deram origem aos precedentes que produziram a súmula.

Outro ponto essencial é o de estabelecer os limites de aplicabilidade de uma súmula e as condições para que ela seja alterada. Há, aqui, um conjunto de saídas que partem da interpretação e da argumentação jurídicas. A primeira é a superação 
do entendimento da súmula, o que demanda fundamentos consistentes e o respeito à estabilidade, à coerência e à integridade da jurisprudência.

Não sendo o caso de superação da súmula, restam duas saídas, muito semelhantes ao raciocício empregado para se afastar a incidência de uma norma a um caso. De um lado, é possível alegar um problema de interpretação, pertinência ou qualificação dos termos jurídicos empregados pela súmula. Aqui, o objetivo do advogado seria afastar a aplicação da súmula suscitando dúvida a respeito de sua adequação ao caso. Por outro lado, os litigantes podem buscar a diferenciação entre os casos que deram origem ao entendimento da Corte com o atual.

\section{REFERÊNCIAS BIBLIOGRÁFICAS}

ASCENSÃO, José de Oliveira. Os acórdãos com força obrigatória geral do Tribunal Constitucional como fontes do direito. Revista do Curso de Direito da Universidade Federal de Uberlândia, Uberlândia, v.16, n.1/2, p.215-229, dez. 1987.

BACHOF, Otto. Normas constitucionais inconstitucionais. Coimbra: Almedina, 2009.

BRASIL. Supremo Tribunal Federal. Proposta de Súmula Vinculante 35. Distrito Federal. Julgamento: 04/02/2010. Publicação: DJ 17/02/2010. Disponível em: <http://www.stf.jus.br/ arquivo/cms/ jurisprudenciaSumulaVinculante/anexo/SUV_31_PSV_35.pdf $>$. Acesso em: 03 nov. 2019.

CANOTILHO, José Joaquim Gomes. Anotação ao acórdão n. ${ }^{\circ}$ 359/91 do Tribunal Constitucional. Revista de Legislação e de Jurisprudência, Coimbra, n.3811, p.318-327, fev. 1992.

CASTANHEIRA NEVES, António. O instituto dos assentos e a função jurídica dos supremos tribunais. Coimbra: Coimbra Editora, 2014.

CROSS, Rupert; HARRIS, J. W. Precedent in English Law. 4.ed. Oxford: Clarendon Press, 1991. 
EISENBERG, Melvin Aron. The nature of the common law. Cambridge: Harvard University Press, 1988.

FARIA, Gustavo Castro. Jurisprudencialização do direito: reflexões no contexto da processualidade democrática. Belo Horizonte: Arraes, 2012.

KOZICKI, Katya. Levando a justiça a sério: interpretação do direito e responsabilidade judicial. Belo Horizonte: Arraes, 2012.

LAPA, Jorge Teixeira. Anotação ao acórdão 810/93: da inconstitucionalidade do assento. Polis: Revista de Estudos Jurídico-Políticos, Lisboa, n.1, p.157-169, out./dez. 1994

LEAL, Victor Nunes. Passado e futuro da súmula do STF. Revista de Direito Administrativo, v. 145. Rio de Janeiro: FGV, p. 1-20, jan. 1981.

MacCORMICK, Neil. Argumentação jurídica e teoria do direito. São Paulo: Martins Fontes, 2006.

MacCORMICK, Neil. Retórica e o estado de direito. São Paulo: Elsevier, 2008.

MACEDO JR., Ronaldo Porto. Do xadrez à cortesia: Dworkin e a teoria do direito contemporânea. São Paulo: Saraiva, 2013.

MANCUSO, Rodolfo de Camargo. Sistema brasileiro de precedentes: natureza, eficácia, operacionalidade. São Paulo: Revista dos Tribunais, 2014.

MARINONI, Luiz Guilherme. Precedentes obrigatórios. 4. ed. São Paulo: Revista dos Tribunais, 2016.

MIRANDA, Jorge. Teoria do Estado e da Constituição. 4. ed. Rio de Janeiro: Forense, 2015.

MITIDIERO, Daniel. Cortes superiores e Cortes supremas. 2. ed. São Paulo: Revista dos Tribunais, 2014.

MITIDIERO, Daniel. Precedentes: da persuasão à vinculação. São Paulo: Revista dos Tribunais, 2016.

PORTUGAL. Código Civil. Disponível em: <http://www.stj.pt/ficheiros/fpstjptlp/portugal_codigocivil.pdf>. Acesso em: 03 nov. 2019. 
PORTUGAL. Supremo Tribunal de Justiça. Acórdão n. ${ }^{\circ}$ 8/2016. Disponível em: $<$ http://www.stj.pt/jurisprudencia/fixada/civel/675-jurisprudencia-fixada-civel-ano2016>. Acesso em: 03 nov. 2019.

PORTUGAL. Superior Tribunal de Justiça. Acórdão n. ${ }^{0}$ 810/93. Polis: Revista de Estudos Jurídico-Políticos, Lisboa, n.1, p.115-169, out./dez. 1994. Disponível em: <http://revistas.lis.ulusiada.pt/ index.php/polis/article/view/932>. Acesso em: 03 nov. 2019.

PORTUGAL. Supremo Tribunal de Justiça. Assento n. ${ }^{0}$ 5/87. No domínio de vigência do Decreto-Lei n. ${ }^{\circ} 46$ 673, de 29 de novembro de 1965, a falta de licença de loteamento não determina a nulidade dos contratos de compra e venda de terrenos, com ou sem construção, compreendida no loteamento. Disponível em: <http://www.stj.pt/jurisprudencia/fixada/civel/284-jfcivel-1987>. Acesso em: 03 nov. 2019.

PORTUGAL. Supremo Tribunal de Justiça. Assento n. ${ }^{\circ}$ 1/92. O recurso de revista de acórdão que conheça do estado de falência tem efeito meramente devolutivo. Disponível em: <http://www.stj.pt/jurisprudencia/fixada/ civel/289-jfcivel-1992>. Acesso em: 03 nov. 2019.

PUGLIESE, 2016. Precedentes e a Civil Law brasileira. São Paulo: Revista dos Tribunais, 2016.

PUGLIESE, William Soares. Princípios da jurisprudência. Belo Horizonte: Arraes, 2017.

VARELA, Antunes. Anotação ao acórdão do Supremo Tribunal de Justiça de 18 de março de 1986. Revista de Legislação e de Jurisprudência, Coimbra, n.3813, p. 365-384, abr. 1992.

ZAGREBELSKY, Gustavo. Il diritto mitte. Torino: Einaudi, 1992.

Data da submissão: 10/10/2019

Data da primeira avaliação: 25/11/2019

Data da segunda avaliação: 02/12/2019

Data da aprovação: 02/12/2019 